УДК 330.322.014.3

DOI: https://doi.org/10.32840/2522-4263/2020-2-30

Kozlovska Anna

Candidate of Philological Sciences, Associate Professor Sumy State University

Kirilieva Anastasiia Student, Sumy State University

Козловська Г.Б. кандидата філологічних наук, доцент, Сумський державний університет

Кіріл'єва А.В. студентка

Сулського державного університету

\title{
FORMATION OF AN EFFECTIVE POLICY OF “GREEN" INVESTMENT AS A PRIORITY DIRECTION OF SUSTAINABLE DEVELOPMENT OF NATIONAL ECONOMY
}

\section{ФОРМУВАННЯ ЕФЕКТИВНОЇ ПОЛІТИКИ «ЗЕЛЕНОГО» ІНВЕСТУВАННЯ ЯК ПРІОРИТЕТНОГО НАПРЯМКУ СТАЛОГО РОЗВИТКУ НАЦІОНАЛЬНОЇ ЕКОНОМІКИ}

\begin{abstract}
ANNOTATION
The article analyzes the current state of "green" investing in the world in general and in Ukraine, in particular. It has been found that strengthening of global economic ties, expansion of integration processes, deepening of the international division of labor and industrial cooperation, gradual liberalization of investment activity, intensification of functioning of TNCs, technological progress, intensification of competition and the desire of companies to enter the international market serve as the driving forces to intensify international investment processes. It is emphasized that, on the one hand, the arrival of a foreign investor is one of the ways of technological structural transformation in the host country. Foreign direct investment is considered suitable for increasing domestic capital, creating jobs while increasing income levels, attracting technology and transferring management skills and knowledge needed to stimulate economic development. On the other hand, FDI can have negative effects, such as "crowding out" of domestic (national) investors, intensifying unfair competition, which can lead to "theft in the market". The environmental impact can be negative, especially when moving polluting industries from one host country to another one, or when FDI in the form of technology is old and unusable. The conclusion shows that the development of "green" investment requires the adoption of strategic documents, the formation of a special policy and its consistent implementation, which will encourage market participants to contribute to the "greening" of the financial sector and the transition to a "green" economy. In order to remove existing obstacles to the development of green financing in Ukraine, it is necessary to apply a systematic and coordinated approach in the areas of regulatory support and institutional support.
\end{abstract}

Keywords: development, investments, green investments, sustainable development, modernization, reform, competitiveness.

\section{АНОТАЦІЯ}

В статті проаналізовано сучасний стан «зеленого» інвестування в світі та в Україні, зокрема. З'ясовано, що зміцнення глобальних економічних зв'язків, розширення інтеграційних процесів, поглиблення міжнародного поділу праці та виробничої кооперації, поступова лібералізація інвестиційної діяльності, активізація функціонування ТНК, технологічний прогрес посилення конкуренції та бажання компаній виходити на міжнародні ринки були рушіями останнього десятиліття з метою активізувати міжнародні інвестиційні процеси. Виокремлено, що з одного боку, приїзд іноземного інвестора є одним із способів технологічної структурної трансформації в країні, що приймає. Прямі іноземні інвестиції вважаються придатними для збільшення внутрішнього капіталу, створення робочих місць при збільшенні рівня доходу, залучення технологій та передачі управлінських навичок та знань, необхідних для стимулювання економічного розвитку. 3 іншого, ПІІ можуть мати негативні наслідки, такі як: «витіснення» внутрішніх (національних) інвесторів, посилення недобросовісної конкуренції, що може призвести до «крадіжок на ринку». Вплив на навколишнє середовище може бути негативним, особливо при переміщенні забруднюючих галузей від країни, що приймає або до країни, що приймає, або коли ПІІ у вигляді технології $є$ старим і непридатним (більше). Зазначено, що принципи «зеленої» економіки та залучення і впровадження «зеленого» інвестування $€$ дієвим механізмом реалізації стратегій сталого розвитку для країн усіх типів політичної системи та рівнів економічного розвитку. «Зелена» економіка $є$ базисом реалізації концепції сталого розвитку на основі більш ефрективного ресурсо- та енергоспоживання, зменшення шкідливого впливу на довкілля та розвитку соціально інтегрованого суспільства. Але «озеленення» економіки вимагає перефоорматування поточних та майбутніх інвестицій для отримання максимально позитивного та довгострокового ефекту. У висновку підсумовано, що розвиток «зеленого» інвестування вимагає прийняття стратегічних документів, фрормування спеціальної політики і її послідовної реалізації, що стимулюватиме учасників ринку сприяти «озелененню» фрінансового сектору і переходу до «зеленої» економіки. 3 метою усунення існуючих перешкод для розвитку «зеленого» фінансування в Україні, необхідним $€$ застосування системного, узгодженого та скоординованого підходу за такими напрямами: нормативно-правове забезпечення та інституційне забезпечення.

Ключові слова: розвиток, інвестиції, «зелені» інвестиції, сталий розвиток, модернізація, реформування, конкурентоспроможність.

\section{АННОТАЦИЯ}

В статье проанализированы современное состояние «зеленого» инвестирования в мире и в Украине в частности. Выяснено, что укрепление глобальных экономических связей, 
расширение интеграционных процессов, углубление международного разделения труда и производственной кооперации, постепенная либерализация инвестиционной деятельности, активизация функционирования ТНК, технологический прогресс, усиление конкуренции и желания компаний выходить на международные рынки были двигателями последнего десятилетия с целью активизации международных инвестиционных процесов. С одной стороны, приезд иностранного инвестора является одним из способов технологической структурной трансформации в принимающей стране. Прямые иностранные инвестиции считаются пригодными для увеличения внутреннего капитала, создание рабочих мест при увеличении уровня дохода, привлечения технологий и передачи управленческих навыков и знаний, необходимых для стимулирования экономического развития. С другой стороны, ПИИ могут иметь негативные последствия, такие как «вытеснение» внутренних (национальных) инвесторов, усиление недобросовестной конкуренции, что может привести к «краже на рынке». Воздействие на окружающую среду может быть отрицательным, особенно при перемещении загрязняющих отраслей от одной принимающей страны или к другой принимающей стране, или когда ПИИ в виде технологии является старым и непригодным (больше). В заключительной части исследования говорится о том, что развитие «зеленого» инвестирования требует принятия стратегических документов, формирование специальной политики и ее последовательной реализации, что, в свою очередь, будет стимулировать участников рынка способствовать «озеленению» финансового сектора и перехода к «зеленой» экономики. С целью устранения существующих препятствий для развития «зеленого» финансирования в Украине, необходимо применение системного, согласованного и скоординированного подхода по следующим направлениям: нормативноправовое обеспечение и институциональное обеспечение.

Ключевые слова: развитие, инвестиции, «зеленые» инвестиции, устойчивое развитие, модернизация, реформирование, конкурентоспособность.

Formulation of the problem in general and its relation to important scientific or practical tasks. All countries strive for development, stability and security. Sustainable development means balancing and maintaining a competitive level of economic, social and ecological environment in the country. A major problem that most countries cannot solve today is that most states cannot create effective mechanisms for developing national well-being and develop efficient and rational use of their own economic and natural resources. It should be noted that only 1 out of 8 billion of the world's population is satisfied with their standard of living. This means that the economy of almost every country requires a comprehensive transformation. The principles of a green economy and attracting and using "green" investment are an effective mechanism for implementing sustainable development strategies for countries of all types of political systems and levels of economic development. The green economy is the basis for realizing the concept of sustainable development on the basis of more efficient resource and energy consumption, reducing the environmental impact and developing a socially integrated society. But "greening" the economy requires reformatting current and future investments to maximize positive and long-term effects.

Analysis of recent studies and publications is the part of our research, in which the disclosures of the basic provisions of the "green" vec- tor of development of the national economy are covered in the works of many famous domestic and foreign scientists. Particularly noteworthy are the works of such authors as Burkinskiy B., Aliyev M., Galushkina T. [1], who reveal the prerequisites, principles and mechanisms of formation of a "green" economy in their research. Musina L. [8] in the works sheds light on ways to solve problems of interaction between the economy and the environment. She successfully and clearly defines the concepts of green economy and green growth, reveals and explains the content of national and strategic documents in this field and compares them with international experience. Nikolaiev Yu. [9] investigates the concept of sustainable eco-innovation development taking into account the integration processes. His works are devoted to the analysis of macroeconomic indicators of stability of the national economy, which are directly dependent on the ecological environment in the country. He focuses on the problem and importance of the interaction between the economic sector and the natural potential of the state. Potapenko V. [11] in his monograph considers the theoretical, methodological, legal and institutional principles of economic security and sustainable development taking into account the ecological transformation of society. This research has a significant contribution as the author looks at the national security of the country through the lens of a green economy.

Among foreign researchers, it is important to single out the works of J.A. Puppim de Oliveira, C.N.H. Doll, O. Balaban [6], who reveal the importance of providing investment environment for attracting foreign funds and introducing environmental trends into the national sustainable development goals of the country's "green" economy in their works. Eaton D. [3] investigates innovative approaches to the development of the national economy, which have been based on the preservation of the environment and the aim of the rational use of the country's natural resources to obtain the long-term economic effects of economic growth of the state.

The aim (goal setting) of this article is to investigate the effectiveness of green investment policy as a priority direction for the sustainable development of the national economy.

Outline of the main research material. Strengthening of the world economic ties, expansion of integration processes, deepening of the international division of labor and industrial cooperation, gradual liberalization of investment activity, intensification of functioning of TNCs, technological progress, growing competition and the desire of enterprises to enter the international markets became the driving forces to intensify international investment processes. And the "weakness" of national capital and the scarcity of domestic investment resources in most countries have increased countries' interest in attracting 
foreign capital (mainly, FDI). These processes, in the light of scientific achievements and practical experience, have influenced the course of discussion by the expert environment of the role and place of FDI in the recipient countries.

On the one hand, the arrival of a foreign investor is one way of technological structural transformation in the recipient country. FDIs are seen as conducive to boosting domestic capital, creating new jobs while raising income levels, attracting technology and transferring management skills and know-how that are essential to stimulate economic development. As a rule, enterprises with foreign capital provide technical assistance to the recipient country, which improves product quality and increases the technological level of the production process itself (reducing the technological gap). FDI can also play an important role in the promotion of environmentally friendly goods and services.

FDI, on the other hand, can lead to negative consequences, such as "crowding out" domestic (national) investors, enhancing unfair competition, which can lead to the "market stealing effect". The environmental impact may be negative, in particular by moving environmentally dirty industries from the basic country to the recipient country, or if the FDI coming in the form of technology is old and unusable (in more detail latert).

Until recently, little attention has been paid to the role of FDI in sustainable development and its impact on green growth. One of the explanations for the limited attention to the contribution of FDI to sustainable development is the lack of a well-defined definition of "green" FDI, as well as sectoral statistics on the flow of "green" FDI across countries. The impact of FDI on the environment - potentially, both positive and negative - has increased interest in the concept of green FDI. International Economic and Financial Organizations - UNCTAD, OECD, UNEP - and the specialized FDI Intelligence and Bloomberg news agencies have taken steps to identify green FDIs, calculate their flows and totals, and evaluate funding gaps that need to be addressed with due consideration of global CDG. Thanks to the above-mentioned analysis and definition of the conceptual apparatus of this definition, we can build our own research and analyze the state of green investment in Ukraine. It is important to note that one of the indicators that shows the effectiveness of the green economy in the country is international rankings. One of the most significant indices is The Global Green Economy Index, GGEI, which ranks 130 countries in the green economy development program under the National Economic Sustainability Program. Accordingly, we consider it advisable to analyze some of the positions in this rating and to identify where Ukraine is in this rating.

Based on available data, we formalize our analysis in the form of a table (Table 1).
Table 1

The Global Green Economy Index, 2018

\begin{tabular}{|c|c|c|}
\hline Rating & Country & Indicator \\
\hline 1 & Sweden & 0.7608 \\
\hline 2 & Switzerland & 0.7594 \\
\hline 3 & Iceland & 0.7129 \\
\hline 4 & Norway & 0.7031 \\
\hline 5 & Finland & 0.6997 \\
\hline 6 & Germany & 0.6890 \\
\hline 7 & Denmark & 0.6800 \\
\hline 8 & Taiwan & 0.6669 \\
\hline 9 & Austria & 0.6479 \\
\hline 10 & France & 0.6405 \\
\hline 120 & Ukraine & 0.3813 \\
\hline
\end{tabular}

Source: generated by authors [5]

Thus, according to Table 1 , we can state that the level of development of the "green" economy is too low, and Ukraine takes 120th place out of 130. The leading positions are occupied by the developed economies and countries that pay considerable attention to the use of "green" economy.

Another important indicator, in our view, is the Environmental Performance Index (ERI), a comprehensive indicator of assessing the environmental policy of the state and its individual entities. The index is calculated on 24 performance indicators across ten categories covering health, environment and ecosystem viability. These indicators make it possible to assess the extent to which countries have achieved the set environmental policy goals (Table 2).

Table 2

Environmental Performance Index, 2018

\begin{tabular}{|c|c|c|c|c|}
\hline Rating & Country & 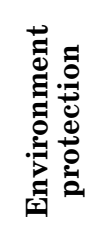 & 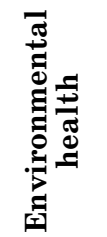 & 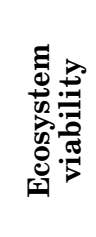 \\
\hline 1 & Switzerland & 87.42 & 93.57 & 83.32 \\
\hline 2 & France & 83.95 & 95.71 & 76.11 \\
\hline 3 & Denmark & 81.60 & 98.20 & 70.53 \\
\hline 4 & Malta & 80.90 & 93.80 & 72.30 \\
\hline 5 & Sweden & 80.51 & 94.41 & 71.24 \\
\hline 109 & Ukraine & 52.87 & 64.44 & 45.16 \\
\hline
\end{tabular}

Source: authored by authors [4]

For many years, Switzerland has remained the leader, a country that has been improving its performance every year (in particular, in 2012, the figure was $76.2 \%$ ). In 2018, Ukraine took 109th place among 132 countries with 52.87\%. Low indicators show the great need to intensify the efforts of the state to ensure sustainable development on a number of factors, such as biodiversity protection, GHG emission reductions, etc. (Table «Environmental Performance Index»).

Therefore, identifying Ukraine's place in the system of world leaders in the field of "green" 
economy, let us find out the current state of "controversial" investment in Ukraine and ways of its development in the future.

In recent years, certain elements of the green investment mechanism have emerged and become widespread in Ukraine. And this happened not primarily as a result of a consistent, strategically oriented policy, but as a result of finding answers to acute current problems of economic development and under the influence of a number of accepted international commitments. In particular, there should be some positive developments in a financial instrument such as green bonds. Under the influence of the high level of interest of both Ukrainian and foreign investors to invest in green bonds, today the question of creating a market of green bonds in Ukraine is very popular among the parliamentarians and experts.

Currently, a number of investment incentives is being used to help solve energy-saving and construction problems of modern power generation facilities, including using RES.

Also, one of the instruments to stimulate the development of green eco-economics in Ukraine was the establishment of a green feed-in tariff, produced from alternative sources. Due to its introduction (since 2009), the construction of wind farms, hydroelectric power plants, small hydropower plants and other stations operating on alternative sources has been intensified. However, the country has not been able to achieve its electricity generation from RES according to state strategy papers yet.

Carrying out a number of reforms and introducing regulatory changes in recent years, such as the implementation of the provisions of the Association Agreement with the EU, led to a certain improvement of the investment climate in Ukraine (despite the unfavorable security and geopolitical factors for Ukraine). In particular, this can be proved by the country's position in the World Bank's Doing Business ranking in recent years. Thus, in the Doing Business 2020 rating, Ukraine has taken 64th place, improving its position, compared to Doing Business 2019, by seven points [2]. The biggest progress was made on the indicators of "protection of minority shareholders", which managed to improve the positions by 27 points and "obtaining a building permit" by 10 points.

At the same time, the introduction of the green investment model and the transition to a fullfledged environmental policy in Ukraine are significantly constrained by the lack of clarity in the formulation of an active environmental policy by the authorities, which is largely influenced by the international community and the domestic public (environmental movements) and organizations.

In addition, it should be noted that the state policy in the sphere of regulating the transition of national business to a green economy is unclear and fragmented. The mirror image of this situation is the lack of a unified position of the national business in the development of the green economy. This is significantly facilitated by the informational closeness of state agencies responsible for solving the problems of greening the economy, investing public funds in specific decisions in the area of sustainable economic development. Therefore, in accordance with all facts mentionrf anove, we formalize the current situation of green investments in Ukraine in the form of a scheme (Figure 1).

In Ukraine, there is no systematic vision for the green growth financing model: its formation has not been completed yet. However, there is still no clear understanding of the role of national financial institutions in the implementation of this course. Initially, green investments were considered as a general economic feasibility of investing in order to prevent and finance environmental pollution, mainly at the expense of international financial institutions. And only today the position has been going to emerge according to which the country should develop its own strategy for financing sustainable development, and this strategy should take into account all sources of funds (public and private, domestic and international).

Thus, in accordance with the facts mentioned above about the current situation of "green" investment activity, it should be noted that such positions are incompatible with the goals of "green" investment, which requires attracting and efficient accumulation of additional financial resources. Interest rates in the economy are still too high (since October 25, 2019 the NBU discount rate is at the level of $15.5 \%$ 7) [10], and the inflation rate remains significant. This, in turn, increases the value of the national currency and private sector borrowing facilities in the national currency. High interest rates reduce the ability of borrowers to invest in "green" programs, including energy efficiency and renewable energy. Ukraine is characterized by a low level of diversification of marketable financial instruments, limited sources of capital mobilization and relatively low rates of financial innovation.

In view of the above-mentioned analysis of the current situation of green investments in Ukraine, there is a need to create a mechanism for attracting and using green investments.

In Ukraine, sustainable economic policy approaches need to be implemented through broad coordination of government actions (such as the Ministry of Economic Development, Trade and Agriculture, the Ministry of Energy and the Environment, the Ministry of Finance, and the NBU in terms of adapting monetary policy to sustainable goals economic development) and private entities, including the Ukrainian Stock Exchange, commercial banks and investment companies and other institutional investors, with a view to agreeing (and in the case of needs and joint) decisions on mobilization, support and capacity building for the development of green markets and environmentally friendly businesses. 


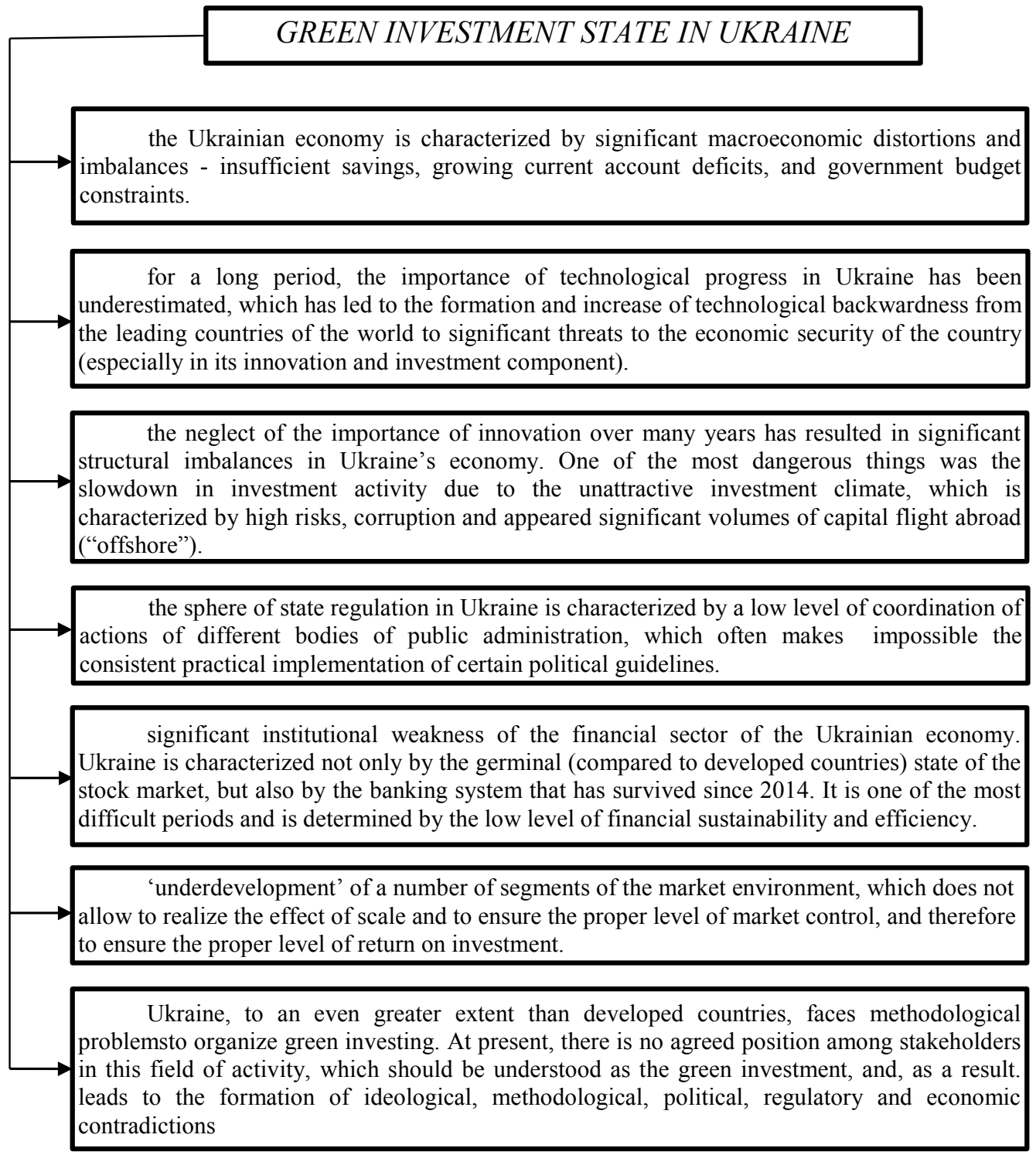

Figure 1. The state of green investment in Ukraine

Source: authored by authors [7, p. 103]

The development of green investment requires the adoption of strategic documents, the formation of a special policy and its consistent implementation, which will stimulate market participants to contribute to the greening of the financial sector and the transition to a green economy. In order to remove existing obstacles to the development of green financing in Ukraine, it is necessary to apply a systematic and coordinated approach in the following areas: regulatory support and institutional support. Let us take a closer look at each of them.

Legal support:

- to define clearly the concept of green investment and legally establish the main priorities of green investment as an important component of the more general concept of green economy, as well as the parameters of its regulation. This is a prerequisite for creating the foundations for effective governance and regulation in this area.
- to raise consistently environmental and environmental quality standards and the amount of sanctions for breaches by all businesses.

- to review the environmental commitments of Ukraine in the face of the worsening climate change problem, which will also lead to a revision of environmental targets both in the country and by industry. In this context, the needs for green investment in the primary, secondary and tertiary sectors of the economy should be assessed (highlighting activities in areas such as green building and modernization of buildings, clean transport, renewable energy and waste management, sustainable agriculture and others).

- to develop and adopt a Green Investment Roadmap, which will identify: (1) the main goals and priorities that faces Ukraine in attracting green investment; (2) major obstacles to green investment; (3) tools and mechanisms for activating green investing; (4) step-by-step instructions 
(tasks) for attracting green investments with the respect of national interests; (5) the directions of state policy in terms of preventing or minimizing the possible outflow of "green" investments under the influence of adverse factors of the market and political environment.

- to ensure the stability of the regulatory framework and tax policy, define a portfolio of green projects, and introduce a transparent public procurement procedure with clearly defined environmental sustainability criteria.

- to ensure the enhancement of the effectiveness of the intellectual property rights protection system, which in the long run will be crucial for attracting investment and creating incentives for innovation, significantly enhancing the incentives to invest in the research and development of products, technologies, "green" invluding [7, p. 203-215].

Institutional support:

- to designate a national agency responsible for green investing and set up a coordination center to ensure interaction and coordination between green project initiators, investors and regulators.

- to incorporate a green agenda into the mandates of public development institutes and public procurement procedures.

- to take steps towards finding a balance and combining the interests of all participants in the investment process. Implementation of the public-private partnership approach in the field of green investments.

- to establish a specialized institution to carry out the expertise of green projects that can be a potential investment object.

In accordance with the characteristics of approaches to improve and introduce innovative elements to the existing green investment system, it is advisable to formulate a mechanism for public private sector incentives for green investment when the following initiatives are visible:

- direct budget financing (subsidizing) of investment measures aimed at creating a modern environmentally friendly infrastructure, especially in the context of the latest technologies of the Fourth Industrial Revolution. Such funding may be provided through public investment programs and priority national projects.

- promoting green innovation by significantly increasing government support for research and development work in low carbon and climate change technologies, which should reduce the cost to private investors and encourage them to invest in new clean technologies.

- supporting private "green" financing through a system of state guarantees (in the case of major high-risk projects), implementation of new market standards and instruments. In particular, the provision of government guarantees for individual issues of green bonds, depending on the level of their social and environmental importance and compliance with the principles and standards established for state-level green bonds.
- developing a risk insurance system for green investment, including the possibility of state insurance for particularly large socially and environmentally significant green projects.

- stimulating the demand for new "green" technologies and creating markets for new "green" products through government demand ("green" public procurement). As an intermediate step in this direction, legislative proposals can be made to integrate environmental and energy efficiency requirements into existing public procurement mechanisms.

- providing the preferential access to publicly owned infrastructure and public services.

- establishing the state-owned banks for green investments or green infrastructure funds to support investments in green infrastructure. A stateowned green bank can overcome the risks that private banks cannot cope with today, thus acting as a catalyst for further private sector investment.

- strengthening of mechanisms of stimulation of "green" investments by increasing the pressure of payments for inefficient and environmentally harmful use of economic resources. First of all, we are talking about carbon pricing schemes and rents for the exploitation of natural resources.

Therefore, in line with the above mentioned points of the mechanism of attracting green investments, we should note that its implementation and practical application and achievement of the goals of sustainable development of national economy will allow to obtain long-term and positive economic effects for all branches of activity of economic entities.

Conclusions. The analysis of the individual impacts of FDI on the components of sustainable development makes it possible to conclude that FDI is an important source of funding for transmission and technology, as well as know-how between countries. However, the impact of green FDI is extremely difficult to assess accurately, since the net benefits of such investments are not automatic and do not increase equally in each country, sector or region, and their volume varies depending on the foreign investor. Also, little is known about the amount of FDI contribution to green growth. The limited understanding of the role of FDI in promoting green growth targets, as noted above, can be explained by the lack of an internationally agreed definition of green FDI and a lack of data on them. Green FDI is believed to be emerging in areas where their environmental impact (energy efficiency, pollution control and reduction, household waste management) is the largest.

\section{REFERENCES:}

1. «Zelena» ekonomika: peredumovy i perspektyvy rozvytku u Ukrayini: informatsiyno-analitychnyy ohlyad [«Green» economy: prerequisites and prospects for development in Ukraine: information and analytical review] / M. Aliyev, B. Burkins'kyy, T. Halushkina ta in. Prohrama dovkillya OON (YUNEP) [Unit- 
ed Nations Environment Program (UNEP)], Institut problem rynka i ekonomiko-ekologicheskikh issledovaniy NAN Ukrainy. Odesa: Feniks, 2012. Pp. 15.

2. Doing Business 2020. Economy Profile Ukraine. World Bank Group. Available at: https://www.doingbusiness.org/content/ dam/doingBusiness/country/u/ukraine/UKR.pdf (accessed 01 March 2020).

3. Eaton D. (2013) Technology and innovation for a green economy. Community. Environmental. Law, vol. 22, no. 1, pp. 62-67. Available at: http://web.b.ebscohost.com/ehost/detail/detail ?sid=9e70cf71-36e6-4f89-9e58-94cf2aafee43\%40sessionmgr111\& (accessed 05 March 2020).

4. Environmental Performance Index. Available at: https://epi. envirocenter.yale.edu/epitopline?country=\&order=field_ epi_score_new\&sort=desc (accessed 05 March 2020).

5. Global Green Economy Index 2018. Dual Citizen (2018) Available at: https://dualcitizeninc.com/global-green-economy-index/ (accessed 03 March 2020).

6. J. A. Puppim de Oliveira Green economy and governance in cities: assessing good governance in key urban economic processes (2013) J. Clean Prod. Vol. 58, pp. 138-152. Available at: www.sciencedirect.com/science/article/pii/S095965 2613005040 (accessed 05 March 2020).

7. Markevych K., Sidenko V. (2019) Zeleni investytsiyi v stalyy rozvytok: svitovyy dosvid ta ukrayins'kyy kontekst [Green Investments in Sustainable Development: World Experience and the Ukrainian Context]. Tsentr Razumkova [Razumkov Center]. Kyyiv: «Zapovit», pp. 316.

8. Musina L. A., Yamchuk A. V., Kvasha T. K. (2012) Vzayemnyy vplyv ekonomiky ta pryrodnoho seredovyshcha $v$ suchasnomu sviti: polityka, stratehiyi, tekhnolohiyi [Mutual influence of economy and natural environment in the modern world: politics, strategies, technologies]. Derzhavne ahentstvo z pytan' nauky, innovatsiy ta informatyzatsiyi Ukrayiny [State Agency for Science, Innovation and Informatization of Ukraine]. Kyyiv: UKRINTEY, pp. 259

9. Nikolayev Yu. O. (2005). Rozvytok ekoinnovatsiy ta makroekonomichna stabil'nist' (teoretychnyy ta metodolohichnyy aspekt) [Eco-innovation development and macroeconomic stability (theoretical and methodological aspect)]. Institut problem rynka i ekonomiko-ekologicheskikh issledovaniy NAN Ukrainy [Institut problem rynka i ekonomiko-ekologicheskikh issledovaniy NAN Ukrainy]. Odesa: Vypusk NAkazu NADU, pp. 340.

10. Ofitsiynyy sayt Natsional'noho banku Ukrayiny [The official site of the National Bank of Ukraine]. Available at: https://bank. gov.ua (accessed 01 March 2020).

11. Potapenko V. H. (2012) Stratehichni priorytety bezpechnoho rozvytku Ukrayiny na zasadakh «zelenoyi ekonomiky» [Strategic priorities for the secure development of Ukraine on the basis of the «green economy»]: monohrafiya. Kyyiv: NISD, pp. 359.

\section{БІБЛІОГРАФІЧНИЙ СПИСОК:}

1. «Зеленая» экономика: предпосылки и перспективы развития в Украине : информационно-аналитический обзор / М. Алиев, Б. Буркинский, Т. Галушкина и др. Программа ООН по окружающей среде (ЮНЕП), Институт проблем рынка и экономико-экологических исследований НАН Украины. Одесса : Фенікс, 2012. 15 с.

2. Doing Business 2020. Economy Profile Ukraine. World Bank Group. URL: https://www.doingbusiness.org/content/dam/ doingBusiness/country/u/ukraine/UKR.pdf (дата звернення: 01.03.2020).

3. Eaton D. Technology and innovation for a green economy. Community. Environmental. Law. 2013. Vol. 22, № 1. Pp. 62-67. URL: http://web.b.ebscohost.com/ehost/detail/deta il?sid=9e70cf71-36e6-4f89-9e58-94cf2aafee43\%40sessionmgr111\& (дата звернення: 05.03.2020).

4. Environmental Performance Index. URL: https://epi.envirocenter.yale.edu/epitopline?country=\&order=field_epi_ score_new\&sort=desc (дата звернення: 05.03.2020).

5. Global Green Economy Index 2018. Dual Citizen, 2018. URL: https://dualcitizeninc.com/global-green-economy-index/ (дата звернення: 03.03.2020).

6. J. A. Puppim de Oliveira Green economy and governance in cities: assessing good governance in key urban economic processes. J. Clean Prod. 2013. Vol. 58. Pp. 138-152. URL: www.sciencedirect.com/science/article/pii/S0959652613 005040 (дата звернення: 05.03.2020).

7. Маркевич К., Сіденко В. «Зелені» інвестиції у сталому розвитку: світовий досвід та український контекст. Центр Разумкова. Київ : «Заповіт», 2019. 316 с.

8. Мусіна Л. А., Ямчук А. В., Кваша Т. К. Взаємний вплив економіки та природного середовища в сучасному світі: політика, стратегії, технології. Державне агентство з питань науки, інновацій та інформатизації України. Київ : УкрIHTEI, 2012. 259 с.

9. Николаев Ю. О. Экоинновационное развитие и макроэкономическая стабильность (теоретико-методологический аспект). Институт проблем рынка и экономикоэкологических исследований НАН Украины. Одесса : ОРІДУ НАДУ, 2005. $340 \mathrm{c}$.

10. Офіційний сайт Національного банку України. URL: https://bank.gov.ua (дата звернення: 01.03.2020).

11. Потапенко В. Г. Стратегічні пріоритети безпечного розвитку України на засадах «зеленої» економіки : монографія. Київ : НІСД, 2012. 359 с. 